\title{
EFEK ANTIINFLAMASI INFUSA RIMPANG TEMU PUTIH (Curcuma zedoaria (Berg) Roscoe) PADA TIKUS YANG DIINDUKSI KARAGENIN
}

\author{
Tanti Azizah Sujono, Raudatul Patimah, Ratna Yuliani \\ Fakultas Farmasi Universitas Muhammadiyah Surakarta \\ Correspondence to: Tanti Azizah Sujono \\ Email : tanti_azizah@ums.ac.id
}

\begin{abstract}
Inflammation is the body's reaction to foreign substances that enter the body with signs of redness, heat, swelling, pain, and impaired organ functions. Curcuma rhizome including medicinal plants that have properties relieve the pain and inflammation of the skin. The purpose of this research was to examine the anti-inflammation effect of Curcuma zedoaria (Berg) Roscoe Rhizome infusion on carrageenan induced paw edema in rats. This research used experimental method with completely randomized design. Twenty five healthy Wistar male rats, 2-3 months old and 150-250 g divided into five groups and each group consist of 5 rats. Rats in group I that served as negative control were given $2.5 \mathrm{~mL} / 200 \mathrm{gbw}$ of aquadest. Rats in group II as positive control were given sodium diclofenac with dose of $6.75 \mathrm{mg} / \mathrm{kgbw}$. Group III, IV, and V were given Curcuma zedoaria (Berg) Roscoe Rhizome infusion with dose of $0.625,1.250$ and $2.500 \mathrm{~g} / \mathrm{kgbw}$, respectively. Treatments were given per oral 1 hour before injection of $0.1 \mathrm{ml}$ carrageenan $1 \%$ subplantar. Rat paw edema volume was measured before and after carrageenan injection. The measurement was done every 0.5 hour for 6 hours observation. Area Under the Curve (AUC) that is calculated from paw edema volume data, was use to calculate percentage of anti-inflammatory effect. Data were analyzed with one way Anova and Least Significant Difference with confidence level 95\%. Infusion of Curcuma zedoaria Rhizome with doses of 0,625, 1,250, and 2,500 $\mathrm{g} / \mathrm{kgbw}$ had anti-inflammatory effect in Wistar male rats which were induced by Carrageenan 1\%. Percentage of anti-inflammation effect $(44,16 \pm 5,11) \%,(48,70 \pm 7,05) \%$, $(59,09 \pm 9,61) \%$ respectively and the effects were equivalent with positive control.
\end{abstract}

Key words: Anti-inflammation, Curcuma zedoaria (Berg) Roscoe, infusion, Carrageenan.

\section{PENDAHULUAN}

Inflamasi atau radang merupakan penyakit yang banyak diderita oleh masyarakat, biasanya ditandai dengan bengkak, nyeri, kemerahan, dan panas. Pengobatan yang selama ini dilakukan kebanyakan menggunakan obat-obat modern yang pada umumnya memiliki efek samping dan relatif mahal (Santoso, 1998). Golongan obat yang saat ini tersedia untuk penyakit radang salah satunya adalah obat antiradang golongan non steroid yang sering dikenal dengan Non Steroidal Anti Inflammatory Drug (NSAID), yaitu suatu golongan obat yang memiliki khasiat sebagai analgesik, antipiretik, dan antiinflamasi. Penggunaan obat-obat antiinflamasi terutama golongan Non Steroidal Anti Inflammatory Drug (NSAID) ini dapat menyebabkan terjadinya ulkus peptik (Robbins dkk., 2007), sehingga perlu dikembangkan penggunaan obat tradisional.
Salah satu tanaman yang dapat dimanfaatkan sebagai obat adalah rimpang dari Curcuma zedoaria (Berg) Roscoe atau rimpang temu putih. Tanaman obat ini mempunyai khasiat antara lain menghilangkan nyeri, sebagai antikanker dan antiinflamasi (Dalimartha, 2005). Rimpang temu putih mempunyai rasa yang sangat pahit dan pedas, sifatnya hangat dan berbau aromatik. Rimpang temu putih mengandung zat warna kuning kurkumin (diarilheptanoid) dan minyak atsiri (Anonim, 2002). Infusa tanaman yang mengandung minyak atsiri harus diserkai setelah dingin, karena jika diserkai panas maka minyak atsiri akan menguap (Anonim, 1995).

Rimpang temu putih (Curcuma zedoaria (Berg) Roscoe) merupakan salah satu tanaman golongan Zingiberaceae sama halnya dengan rimpang temulawak (Curcuma xanthorriza Roxb). Penelitian beberapa tanaman obat pada tikus 
putih telah membuktikan bahwa infusa rimpang temulawak (Curcuma xanthorriza Roxb) dapat berkhasiat sebagai antiinflamasi (Anonim, 2009). Rimpang temu putih mengandung kurkumin, minyak atsiri dan flavonoid. Kurkumin telah dilaporkan mempunyai efek antiinflamasi pada mencit yang diinduksi karagenin. Mekanisme aktivitas kurkumin sebagai antiinflamasi adalah dengan menghambat produksi prostaglandin yang dapat diperantarai melalui penghambatan aktivitas enzim siklooksigenase (Sudjarwo, 2003) dan kemampuannya mengikat radikal bebas oksigen yang dapat menyebabkan proses peradangan (Anonim, 2000). Selain itu, penelitian sebelumnya membuktikan bahwa minyak atsiri Curcuma zedoaria dosis $800 \mathrm{mg} / \mathrm{kgBB}$ sudah dapat menghambat pembentukan radang pada tikus putih galur Wistar (Anonim, 2002).

Berdasarkan uraian inilah dilakukan penelitian mengenai khasiat antiinflamasi rimpang temu putih menggunakan metode infundasi. Pada pembuatan infusa rimpang temu putih dilakukan penyerkaian setelah dingin, untuk menghindari hilangnya minyak atsiri yang mempunyai efek antiinflamasi, karena minyak atsiri merupakan senyawa yang mudah menguap. Hasil penelitian yang diperoleh diharapkan dapat memberikan informasi tambahan mengenai manfaat penggunaan tanaman temu putih sebagai salah satu obat alami yang berkhasiat sebagai antiinflamasi atau anti radang.

\section{METODE PENELITIAN}

1. Alat: Spuit injeksi (terumo), jarum oral, pletismometer, stopwatch, neraca analitik (kepekaan 0,1mg), timbangan hewan uji, dan alat-alat gelas (pyrex).

\section{Bahan}

a. Serbuk rimpang temu putih diperoleh dari Balai Besar Penelitian dan Pengembangan Tanaman Obat dan Obat Tradisional (B2P2T2OT) Tawangmangu.

b. Bahan kimia: Na-diklofenak, karagenin, Na-klorida dan akuades.

c. Hewan uji : tikus putih jantan galur Wistar berumur 2-3 bulan, berat badan 150-200g dari Pengembangan Hewan Percobaan (UPHP) UGM, Yogyakarta.

Pembuatan Infusa Rimpang Temu Putih: Serbuk rimpang temu putih dibasahi dengan air sebanyak $2 \mathrm{x}$ berat bahan. Rimpang temu putih ditambah dengan air dan dipanaskan di atas penangas air selama 15 menit pada suhu $90^{\circ} \mathrm{C}$, sambil sesekali diaduk dan dibiarkan sampai benar-benar dingin. Kemudian infusa diserkai dengan kain flanel dan ditambahkan dengan air dingin secukupnya dengan dialirkan melalui ampas sehingga diperoleh volume infusa yang dikehendaki.

Pembuatan Larutan Karagenin 1\%: Sebanyak 0,1 gram karagenin ditimbang, dilarutkan dalam larutan fisiologis $\mathrm{NaCl}$ sampai $10 \mathrm{ml}$ (larutan fisiologis $\mathrm{NaCl}$ 0,9\%).

Pembuatan Radang: Radang dibuat dengan cara menginjeksikan sebanyak $0,1 \mathrm{ml}$ larutan karagenin 1\% secara subplantar pada telapak kaki tikus. Telapak kaki tikus ditandai sebatas mata kaki dan diukur volume edemanya dengan alat plestismometer.

Penetapan Dosis Na Diklofenak: Dosis terapi Na Diklofenak pada orang dewasa 75-150 $\mathrm{mg}$ /hari terbagi 2 atau 3 dosis (Anonim, 2002). Faktor konversi dosis pada manusia dengan berat badan $70 \mathrm{~kg}$ ke tikus 200 gram adalah 0,018. Sehingga penetapan dosisnya:

$75 \mathrm{mg} \times 0,018=1,35 \mathrm{mg} / 200 \mathrm{~g}=6,75 \mathrm{mg} /$ $\mathrm{KgBB}$.

Dosis Infusa Rimpang Temu Putih: Dosis infusa rimpang temu putih berorientasi pada konsentrasi 10\% dari konsentrasi infusa (Anonim, 1979) sehingga dibuat kelompok perlakuan dengan konsentrasi $5 \%, 10 \%$, dan $20 \%$ dengan volume pemberian untuk tikus adalah $2,5 \mathrm{~mL} / 200$ gramBB. Infusa rimpang temu putih sebanyak 2,5 $\mathrm{mL}$ per oral diberikan untuk tikus dengan berat badan 200 gram, maka dosis infusa rimpang temu putih yang diberikan berturut-turut adalah sebanyak $0,625,1,250$, dan 2,5 g/kgBB.

Uji Pendahuluan Efek Udem Karagenin

1\%: Uji efek udem karagenin 1\% dilakukan untuk mengetahui bahwa hewan uji yang telah disuntik karagenin $1 \%$ benar-benar sudah mengalami udem. Sebanyak 6 ekor hewan uji dibagi menjadi 2 kelompok, masing-masing 3 ekor hewan uji. Kaki tikus ditandai sebatas mata kaki dan diukur volumenya menggunakan alat plestimometer sebagai volume awal kaki tikus. Kelompok A diinjeksi dengan karagenin 1\% secara subplantar sedangkan kelompok B tanpa diberi perlakuan, kemudian diukur volumenya sebagai waktu ke-0 dan tiap 0,5 jam selama 6,5 jam. 
Orientasi Dosis Na-diklofenak: Penetapan dosis Na-diklofenak 9 ekor hewan uji di bagi menjadi 3 kelompok perlakuan. Masing-masing kelompok 3 ekor tikus. Kaki tikus ditandai sebatas mata kaki dan diukur volumenya menggunakan alat pletismometer sebagai volume kaki awal tikus. Na-diklofenak yang digunakan adalah dosis 6,75 dan $13,5 \mathrm{mg} / \mathrm{kgBB}$ yang diberikan secara per oral.

Pemberian dilakukan 1 jam sebelum kaki tikus diinduksi larutan secara subplantar dengan $0,1 \mathrm{ml}$ larutan karagenin 1\%. Volume kaki tikus diukur pada pletismometer sesaat setelah diinjeksi karagenin sebagai volume waktu ke-0 dan tiap 0,5 jam selama 6 jam.

\section{Penetapan Waktu Pemberian Na-} diklofenak dengan Dosis 6,75 mg/kgBB: Penetapan waktu pemberian Na-diklofenak, 9 ekor hewan uji dibagi menjadi 3 kelompok, masing-masing 3 ekor hewan uji. Kaki tikus ditandai sebatas mata kaki dan diukur volumenya menggunakan alat pletismometer sebagai volume kaki awal tikus. Na-diklofenak dosis $6,75 \mathrm{mg} /$ $\mathrm{kgBB}$ diberikan secara per oral $2,5 \mathrm{~mL} / 200 \mathrm{gBB}$ tikus pada waktu sesaat, 0,5 jam, dan 1 jam sebelum diberikan penyuntikan karagenin 1\% secara subplantar. Volume kaki tikus diukur pada pletismometer sesaat setelah diinjeksi karagenin sebagai volume waktu ke- 0 dan setiap 0,5 jam selama 6 jam.

Penetapan Dosis dan Waktu Pemberian Infusa Rimpang Temu Putih: Pada penetapan dosis dan waktu pemberian infusa rimpang temu putih ini, hewan uji dibagi menjadi 3 kelompok, masing-masing sebanyak 3 ekor tikus. Hewan uji pada kelompok A diberikan infusa rimpang temu putih dengan dosis $1,250 \mathrm{~g} / \mathrm{kgBB}$ diberikan per oral, sesaat kemudian disuntikkan karagenin $1 \%$. Hewan uji kelompok B diberikan infusa rimpang temu putih dosis $1,250 \mathrm{~g} / \mathrm{kgBB}$ diberikan per oral dan setelah 0,5 jam disuntikkan karagenin 1\% dan Hewan uji Kelompok C diberikan infusa rimpang temu putih dosis $1,250 \mathrm{~g} / \mathrm{kgBB}$ diberikan per oral dan setelah 1 jam disuntikkan karagenin $1 \%$. Volume kaki tikus diukur pada pletismometer sesaat setelah diinjeksi karagenin sebagai volume waktu ke-0 dan tiap 0,5 jam selama 6 jam.

Uji efek antiinflamasi infusa rimpang temu putih pada tikus putih jantan galur Wistar: Dua puluh lima ekor tikus putih jantan galur Wistar dipuasakan selama 18-24 jam. Hewan uji dibagi menjadi 5 kelompok, masingmasing kelompok terdiri dari 5 ekor tikus yang dipilih secara acak. Kaki tikus sebelah kiri ditandai sebatas mata kaki dengan spidol ujung runcing dan diukur volume kakinya dengan pletismometer sebagai volume kaki awal (Vo). Kemudian tikus diberi perlakuan per oral dengan sediaan uji volume $2,5 \mathrm{~mL} / 200 \mathrm{gBB}$. Perlakuan ini dilakukan satu jam sebelum induksi karagenin. Induksi 0,1 $\mathrm{ml}$ karagenin 1\% dilakukan pada kaki tikus secara subplantar. Setelah tikus diinduksi, kemudian diukur volume kaki tikus yang sudah ditandai dengan pletismometer setiap 0,5 jam sampai volume udem kaki tikus turun (Vt).

Data yang diperoleh dari uji efek antiinflamasi adalah data volume kaki tikus yang diberi perlakuan.Volume udem merupakan selisih dari volume kaki sebelum dan sesudah diradangkan dengan karagenin 1\%.

Perhitungan dapat dilakukan dengan rumus:

$$
\mathrm{Vu}=\mathrm{Vt}-\mathrm{Vo}
$$

\section{Keterangan:}

$\mathrm{Vu}$ : Volume udem kaki tikus tiap waktu $\mathrm{t}$

Vt : Volume kaki tikus setelah diradangkan dengan karagenin $1 \%$ pada waktu tertentu

Vo : Volume awal kaki tikus sebelum diradangkan dengan karagenin 1\%.

Data kuantitatif penelitian berupa AUC (Area Under the Curve) dari kurva volume udema rata-rata terhadap waktu dan persen efek antiinflamasi. Nilai AUC (Area Under the Curve) yaitu luas daerah rata-rata di bawah kurva yang merupakan hubungan volume udem rata-rata tiap satuan waktu dengan rumus:

$$
\mathrm{AUC}_{\mathrm{t}_{\mathrm{n}-1}}^{\mathrm{t}_{\mathrm{n}}}=\frac{\mathrm{Vt}_{\mathrm{n}-1}+\mathrm{Vt}_{\mathrm{n}}}{2}\left(\mathrm{t}_{\mathrm{n}}-\mathrm{t}_{\mathrm{n}-1}\right)
$$

Keterangan:

$\mathrm{Vt}_{\mathrm{n}-1}$ : Volume udem rata-rata pada $\mathrm{t}_{\mathrm{n}-1}$

$\mathrm{Vt}_{\mathrm{n}}$ : Volume udem rata-rata pada $\mathrm{t}_{\mathrm{n}}$

Persen daya antiinflamasi (penghambatan volume udem) dihitung berdasarkan persen penurunan udem menggunakan rumus:

$\%$ Daya Antiinflamasi =

$$
\frac{\mathrm{AUC}_{\mathrm{k}}-\mathrm{AUC}_{\mathrm{p}}}{\mathrm{AUC}_{\mathrm{k}}} \times 100 \%
$$


Keterangan:

$\mathrm{AUC}_{\mathrm{k}}$ : AUC kurva volume udem rata-rata terhadap waktu untuk kontrol negatif.

$\mathrm{AUC}_{\mathrm{p}}$ : AUC kurva volume udem terhadap waktu untuk kelompok perlakuan pada tiap individu.

Tahap awal analisis statistik hasil penelitian dilakukan dengan tes KolmogorovSmirnov yang digunakan untuk mengetahui apakah data hasil penelitian terdistribusi normal atau tidak, Levene Test untuk mengetahui homogenitas variannya, karena data terdistribusi normal dan homogen maka dilanjutkan analisis varian satu jalan (Oneway Anova) dengan taraf kepercayaan 95\%. Setelah diuji Oneway Anova ternyata mendapatkan nilai $\mathrm{p}<0,05$, yang berarti terdapat sedikitnya dua kelompok data yang berbeda bermakna maka dilanjutkan dengan melakukan analisis Post Hoc Test dengan uji LSD (Least Significant Difference) untuk mengetahui data yang memiliki perbedaan bermakna. Untuk mengolah data digunakan program komputer Microsoft Excel dan SPSS versi 17.

\section{HASIL DAN PEMBAHASAN}

Bahan yang dapat digunakan untuk menginduksi terbentuknya udem antara lain mustard oil 5\%, dextran 1\%, serotonin kreatinin sulfat, egg white fresh undiluted dan juga karagenin yang diinduksikan subplantar pada kaki tikus (Vogel, 2008). Karagenin merupakan suatu polisakarida sulfat bermolekul besar sebagai induktor inflamasi (Corsini et al, 2005). Penggunaan karagenin mempunyai beberapa kelebihan antara lain tidak meninggalkan bekas, tidak menimbulkan kerusakan jaringan serta jika dibandingkan dengan senyawa iritan lainnya, karagenin memberikan respon yang lebih peka terhadap obat inflamasi (Siswanto dan Nurulita, 2005). Pada proses pembentukan udem, karagenin akan menginduksi cedera sel dengan dilepaskannya mediator yang mengawali proses inflamasi. Udem yang disebabkan oleh karagenin bisa bertahan selama 6 jam dan berangsur-angsur berkurang dalam waktu 24 jam. Udem yang terjadi akibat terlepasnya mediator inflamasi seperti histamin, bradikinin, prostaglandin. Udem yang disebabkan oleh injeksi karagenin diperkuat oleh mediator inflamsi terutam PGE1 dan PGE2 melalui penurunan permeabilitas vaskuler. Jika permeabilitas kapiler turun akan mengakibatkan protein-protein plasma menuju ke jaringan yang luka sehingga terjadi udem (Corsini et al, 2005).

Uji pendahuluan yang pertama dilakukan adalah uji efek udem yaitu uji untuk mengetahui bahwa karagenin $1 \%$ yang digunakan benarbenar sudah menghasilkan udem dan juga dapat digunakan untuk mengetahui model udem (gambar 1).

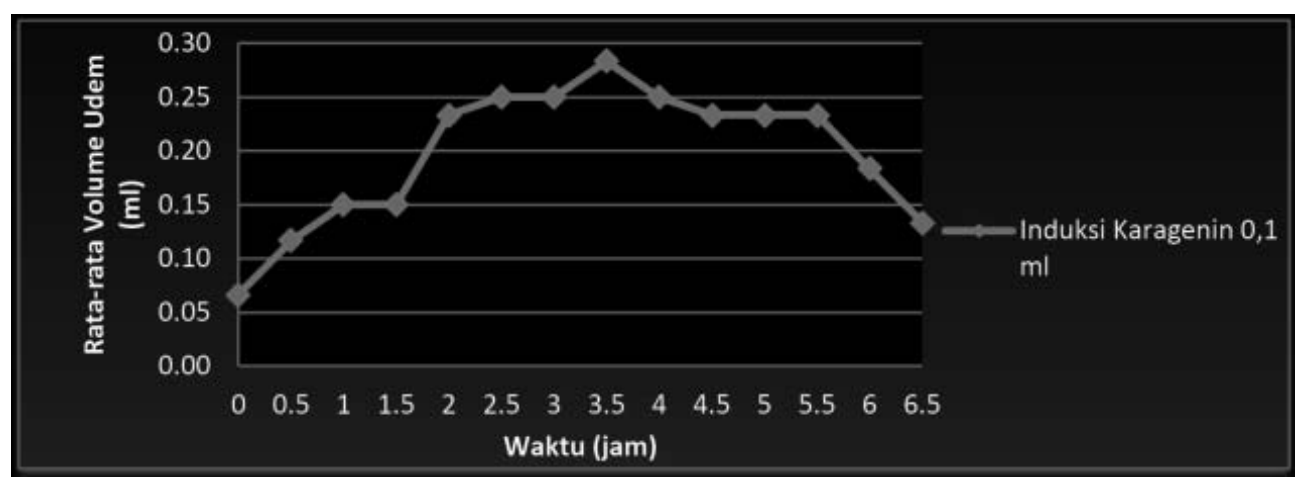

Gambar 1. Grafik Volume Udem kaki tikus setelah diinduksi karagenin

Karagenin $1 \%$ ternyata sudah mampu menimbulkan udem, hal ini ditunjukkan oleh grafik volume udem dimana terlihat bahwa volume kaki tikus yang diinduksi dengan karagenin $0,1 \mathrm{ml}$ mengalami kenaikan (gambar 1).

Uji pendahuluan yang kedua adalah orientasi dosis kontrol positif Na-diklofenak yaitu
$6,75 \mathrm{mg} / \mathrm{kgBB}$ dan $13,5 \mathrm{mg} / \mathrm{kgBB}$ secara per oral. Orientasi dosis dilakukan untuk mengetahui dosis obat yang sudah cukup untuk dapat memberikan efek antiinflamasi pada kaki tikus putih jantan galur Wistar yang diinjeksi karagenin 1\% secara subplantar, Na-diklofenak pada dosis $13,5 \mathrm{mg} /$ $\mathrm{kgBB}$ menunjukkan penghambatan volume udem 
yang lebih baik daripada dosis $6,75 \mathrm{mg} / \mathrm{kgBB}$ dan kontrol negatif. Hal ini ditunjukkan dari grafik volume udem rata-rata dimana Na-diklofenak dosis $13,5 \mathrm{mg} / \mathrm{kgBB}$ memiliki kurva paling rendah dibandingkan dosis $6,75 \mathrm{mg} / \mathrm{kgBB}$ dan kontrol negatif (gambar 2)

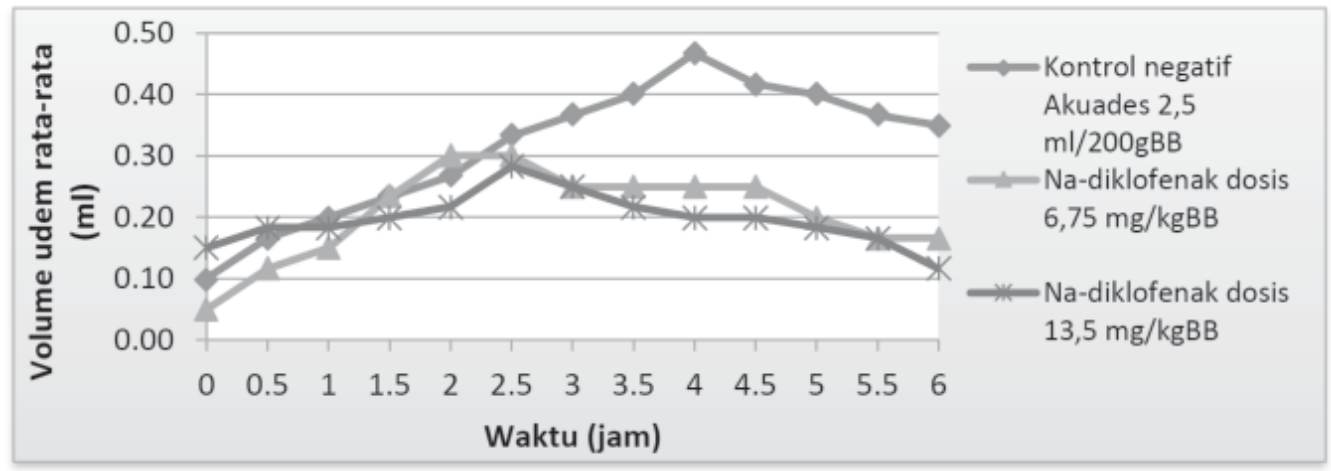

Gambar 2. Grafik Volume Udem Kontrol Negatif Akuades, Na-diklofenak 6,75 dan 13,5 mg/kgBB Waktu 1 Jam Sebelum Karagenin 1\%

Na-diklofenak dosis 6,75 dan 13,5 mg/ kgBB hasilnya menunjukkan tidak ada perbedaan yang bermakna $(p>0,05)$ sehingga untuk uji selanjutnya digunakan dosis yang kecil yaitu 6,75 $\mathrm{mg} / \mathrm{kgBB}$ sebagai kontrol positif. Uji pendahuluan ketiga adalah orientasi waktu pemberian $\mathrm{Na}-$ diklofenak dosis $6,75 \mathrm{mg} / \mathrm{kgBB}$. Waktu pemberian yang akan diorientasi adalah waktu sesaat, 0,5 jam, dan 1 jam sebelum injeksi karagenin 1\%. Na-diklofenak dosis $6,75 \mathrm{mg} / \mathrm{kgBB}$ waktu 1 jam sebelum injeksi karagenin 1\% memiliki kurva paling rendah dibandingkan waktu sesaat dan 0,5 jam sebelum induksi karagenin, yang berarti pada waktu pemberian 1 jam sebelum induksi karagenin mempunyai waktu yang optimal untuk memberikan efek antiinflamasi (gambar 3)

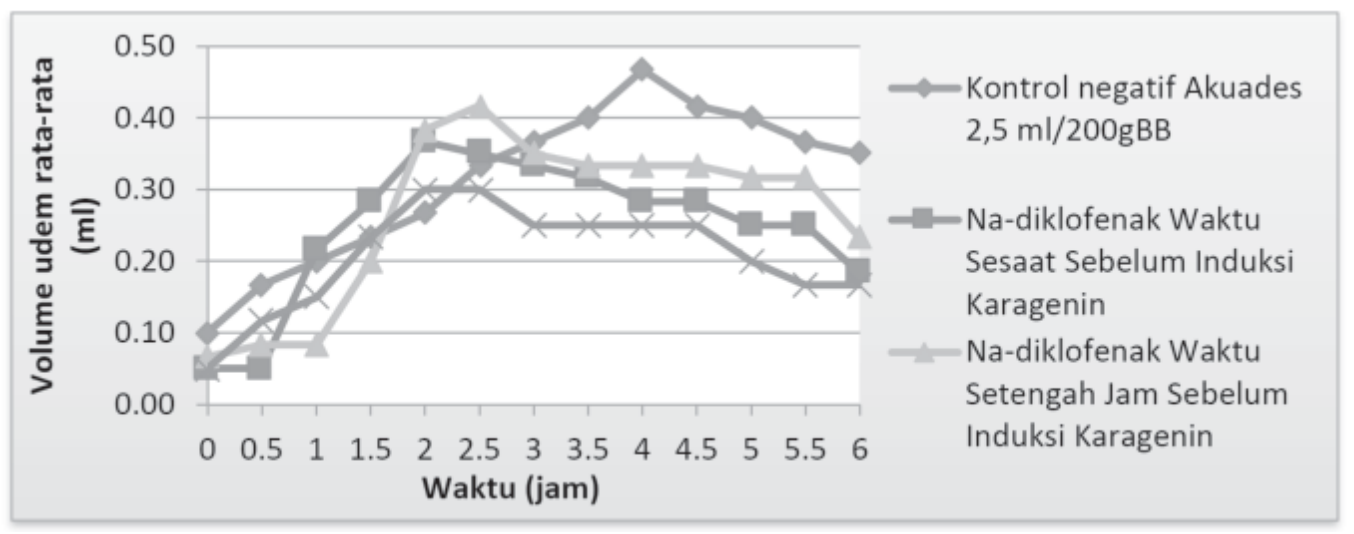

Gambar 3. Grafik Volume Udem Orientasi Waktu Pemberian Na-diklofenak 6,75 mg/kgBB

Dosis $6,75 \mathrm{mg} / \mathrm{kgBB} 1$ jam sebelum injeksi karagenin $1 \%$ ternyata berbeda bermakna dengan kontrol negatif akuades $(p<0,05)$, sedangkan Na-diklofenak $6,75 \mathrm{mg} / \mathrm{kgBB}$ waktu sesaat dan 0,5 jam sebelum injeksi karagenin berbeda tidak bermakna ( $p>0,05)$, sehingga untuk uji selanjutnya dipilih waktu pemberian 1 jam sebelum injeksi karagenin 1\%. Hal ini dapat dilihat pada Gambar 3 , dari grafik volume udem rata-rata dimana $\mathrm{Na}-$ diklofenak dosis $6,75 \mathrm{mg} / \mathrm{kgBB} 1$ jam sebelum injeksi karagenin $1 \%$ memiliki kurva paling rendah dibandingkan waktu sesaat dan 0,5 jam. Untuk uji penetapan dosis infusa rimpang temu putih dan waktu pemberiannya, dosis yang digunakan untuk orientasi yaitu dosis $1,250 \mathrm{~g} / \mathrm{kgBB}$ yang setara dengan kadar infusa $10 \%$. Infusa rimpang temu putih waktu sesaat sebelum induksi karagenin mempunyai kurva yang paling rendah, artinya pada waktu tersebut kadar infusa rimpang temu putih dalam darah sudah cukup menghasilkan efek antiinflamasi (gambar 4) 


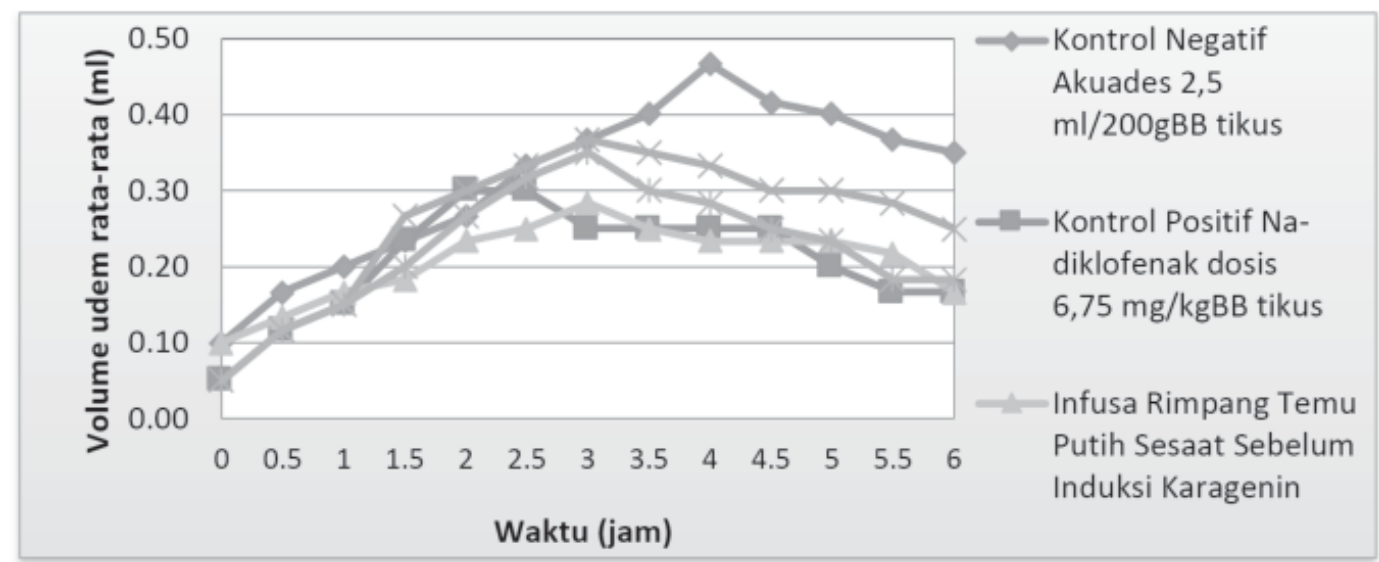

Gambar 4. Grafik Volume Udem Orientasi Waktu Pemberian Infusa Rimpang Temu Putih 1,250 g/kgBB

Dari hasil uji LSD diketahui bahwa infusa rimpang temu putih $1,250 \mathrm{~g} / \mathrm{kgBB}$ sesaat dan 1 jam sebelum injeksi karagenin $1 \%$ ternyata berbeda bermakna dengan kontrol negatif akuades $(\mathrm{p}<0,05)$, artinya infusa rimpang temu putih pada waktu pemberian tersebut sudah dapat memberikan efek antiinflamasi, sedangkan infusa rimpang temu putih $1,250 \mathrm{~g} / \mathrm{kgBB} 0,5 \mathrm{jam}$ sebelum injeksi karagenin berbeda tidak bermakna $(p>0,05)$. Waktu pemberian infusa rimpang temu putih waktu sesaat dan 1 jam sebelum injeksi karagenin $1 \%$ berbeda tidak bermakna satu sama lain, sehingga dapat dipilih waktu pemberian infusa rimpang temu putih sesaat atau 1 jam sebelum injeksi karagenin 1\%.

Pengujian efek antiinflamasi dilakukan pada tikus putih jantan galur Wistar, pada pengujian ini digunakan konsentrasi infusa rimpang temu putih $5 \%$ (setara $0,625 \mathrm{~g} / \mathrm{kgBB}$ ), infusa rimpang temu putih $10 \%$ (setara $1,250 \mathrm{~g} / \mathrm{kgBB}$ ), dan infusa rimpang temu putih $20 \%$ (setara $2,500 \mathrm{~g} / \mathrm{kgBB}$ ) diberikan per oral dengan waktu pemberian 1 jam sebelum injeksi karagenin 1\%. Kontrol positif yang digunakan adalah Na-diklofenak dosis $6,75 \mathrm{mg} / \mathrm{kgBB}$ per oral yang diberikan 1 jam sebelum injeksi karagenin $1 \%$, sedangkan kontrol negatifnya adalah akuades $2,5 \mathrm{ml} / 200 \mathrm{gBB}$ tikus yang diberikan secara per oral. Pengujian dilakukan dengan mengukur volume udem kaki tikus berturut-turut setiap 0,5 jam selama 6 jam pengamatan.

Efek antiinflamasi infusa rimpang temu putih dosis 2,500 $\mathrm{g} / \mathrm{kgBB}$ mempunyai kurva paling rendah dibandingkan kontrol negatif, infusa rimpang temu putih dosis 0,675 dan $1,250 \mathrm{~g} / \mathrm{kgBB}$ yang berarti kemampuannya dalam menghambat udem lebih baik dari ketiga perlakuan (gambar 5). Berdasarkan perhitungan persentase DAI (Daya Antiinflamasi), efek antiinflamasi infusa rimpang temu putih dosis 2,500 $\mathrm{g} / \mathrm{kgBB}$ paling besar jika dibandingkan dengan dosis $0,625 \mathrm{~g} /$ $\mathrm{kgBB}$, dosis $1,250 \mathrm{~g} / \mathrm{kgBB}$, dan Na-diklofenak $6,75 \mathrm{mg} / \mathrm{kgBB}$. Sehingga dapat diketahui bahwa efek antiinflamasi paling besar dimiliki oleh infusa rimpang temu putih dosis $2,500 \mathrm{~g} / \mathrm{kgBB}$; kemudian Na-diklofenak $6,75 \mathrm{mg} / \mathrm{kgBB}$ sebagai kontrol positif, infusa rimpang temu putih dosis $1,250 \mathrm{~g} / \mathrm{kgBB}$, dan dosis $0,625 \mathrm{~g} / \mathrm{kgBB}$.

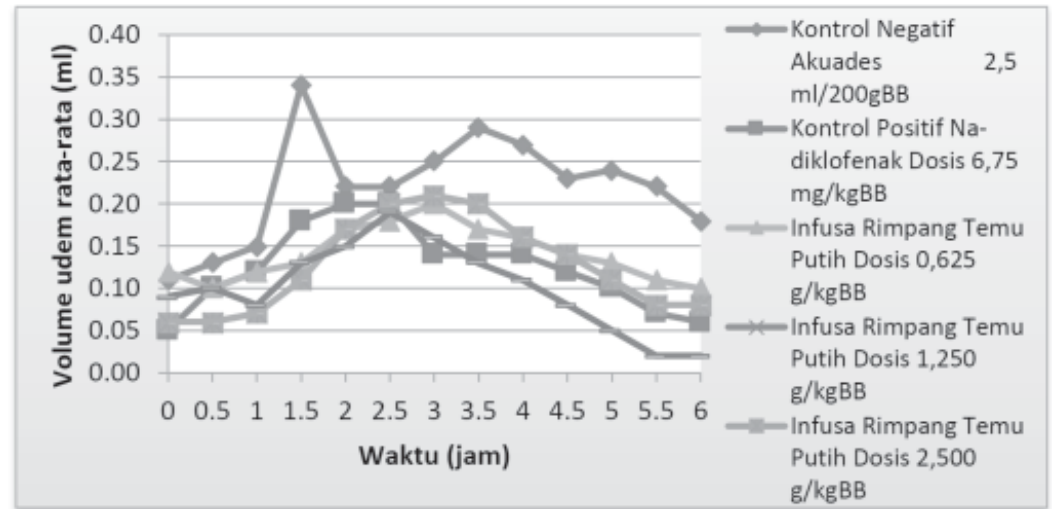

Gambar 5. Grafik Volume Udem Uji Efek Antiinflamasi Infusa Rimpang Temu Putih 
Harga AUC (Area Under the Curve), yaitu luas daerah di bawah kurva antara ratarata volume udem terhadap waktu, dianalisis statistik menggunakan uji Kolmogorov Smirnov dan diperoleh hasil data terdistribusi normal, pada Levene test didapatkan data homogen lalu dilanjutkan perhitungan $L S D$. Dari perhitungan menunjukkan bahwa kontrol positif Na-diklofenak $6,75 \mathrm{mg} / \mathrm{kgBB}$, infusa rimpang temu putih dosis $0,625 \mathrm{~g} / \mathrm{kgBB}$, dosis $1,250 \mathrm{~g} / \mathrm{kgBB}$, dan dosis $2,500 \mathrm{~g} / \mathrm{kgBB}$ berbeda bermakna dengan kontrol negatif akuades, artinya Na-diklofenak dan infusa rimpang temu putih dengan konsentrasi tersebut mempunyai efek antiinflamasi.

Hasil uji $L S D$ dengan taraf kepercayaan 95\% menunjukkan bahwa kontrol positif Nadiklofenak $6,75 \mathrm{mg} / \mathrm{kgBB}$ berbeda tidak bermakna dengan infusa rimpang temu putih dosis $0,625 \mathrm{~g} /$ $\mathrm{kgBB}$, dosis $1,250 \mathrm{~g} / \mathrm{kgBB}$, dan dosis $2,500 \mathrm{~g} /$ kgBB 1 jam sebelum injeksi karagenin 1\%. Hal ini berarti infusa rimpang temu putih memiliki kemampuan menghambat inflamasi sebanding dengan Na-diklofenak 6,75 mg/kgBB (Tabel 1).

Tabel 1. Hasil Uji LSD Persen Daya Antiinflamasi Infusa Rimpang Temu Putih

\begin{tabular}{lcc}
\hline \multicolumn{1}{c}{ Kelompok } & Nilai AUC (ml.jam) Mean \pm SEM & \% Daya Antiinflamasi Mean \pm SEM \\
\hline Kontrol negatif (Aquades $2,5 \mathrm{~mL} / \mathrm{kgBB})$ & $1,54 \pm 0,17$ & - \\
Kontrol positif (Na. Diklofenak $6,75 \mathrm{mg} / \mathrm{kgBB})$ & $0,78 \pm 0,18^{*}$ & $49,09 \pm 11,81$ \\
Infusa rimpang temu putih $0,675 \mathrm{~g} / \mathrm{kgBB}$ & $0,86 \pm 0,08^{*}$ & $44,16 \pm 5,11$ \\
Infusa rimpang temu putih $1,250 \mathrm{~g} / \mathrm{kgBB}$ & $0,79 \pm 0,11^{*}$ & $48,70 \pm 7,05$ \\
Infusa rimpang temu putih $2,500 \mathrm{~g} / \mathrm{kgBB}$ & $0,63 \pm 0,15^{*}$ & $59,09 \pm 9,61$ \\
\hline
\end{tabular}

Keterangan : * berbeda bermakna $(\mathrm{p}<0,05)$

Rimpang temu putih mengandung minyak atsiri, flavonoid dan kurkumin. Berdasarkan penelitian sebelumya, kurkumin dilaporkan dapat bersifat sebagai antiinflamasi pada mencit yang diinduksi karagenin. Mekanisme aktivitas kurkumin sebagai antiinflamasi adalah dengan menghambat produksi prostaglandin yang dapat diperantarai melalui penghambatan aktivitas enzim siklooksigenase (Sudjarwo, 2003) dan kemampuannya mengikat radikal bebas oksigen yang dapat menyebabkan proses peradangan (Anonim, 2000).

\section{KESIMPULAN}

Infusa rimpang temu putih konsentrasi 5\%, $10 \%$, dan $20 \%$ atau setara dengan dosis 0,$625 ; 1,250$ dan 2,500 g/kgBB mempunyai efek antiinflamasi pada tikus yang diinduksi karagenin dengan persen daya antiinflamasi berturut-turut $(44,16 \pm 5,11) \%$, $(48,70 \pm 7,05) \%$, dan $(59,09 \pm 9,61) \%$.

\section{SARAN}

Perlu dilakukan penelitian yang lebih lanjut untuk mengetahui kandungan kimia infusa rimpang temu putih (Curcuma zedoaria (Berg) Roscoe) yang mempunyai efek sebagai antiinflamasi.

\section{Persantunan}

Fakultas Farmasi Universitas Muhammadiyah Surakarta yang telah membantu memberikan dana untuk penelitian ini melalui Penelitian Kolaboratif Dosen dan Mahasiswa.

\section{DAFTAR PUSTAKA}

Anonim, 1995, Farmakope Indonesia, Edisi Keempat, IV, Departemen Kesehatan Republik Indonesia, Jakarta.

Anonim, 2000, Acuan Sediaan Herbal, Edisi I, Departemen Kesehatan RI, Dirjen Pengawasan Obat dan Makanan, Jakarta.

Anonim, 2009, Penelitian Efek Antiinflamasi Beberapa Tanaman Obat pada Tikus Putih, Pusat Penelitian Dan Pengembangan Farmasi, Badan Penelitian dan Pengembangan Kesehatan Departemen Kesehatan R.I., Jakarta.

Corsini, E., Paola R.D., Viviani, B., Genovese, T., Mazzon, E., Lucchi, L., et al., 2005, Increased Carrageenan-Induced Acute Lung Inflammation in Old Rats, Immunology, 115 (2):253-61.

Dalimartha, S., 2005, Atlas Tanaman Obat Indonesia, Jilid 3, Cetakan ke-4, 170-171, Puspa Swara, Jakarta. 
Robbins, S., Kumar, V., dan Cotran R. S., 2007, Buku Ajar Patologi, Diterjemahkan oleh Pendit, B., Edisi 7, Buku Kedokteran EGC, 625627, Jakarta.

Santoso, H. B., 1998, Tanaman Obat Keluarga III, Kanisius, Jakarta.

Siswanto, A., dan Nurulita, N.A., 2005, Daya Antiinflamasi Infus Daun Mahkota dewa (Phaleria macrocarpa Scheff Boerl) pada Tikus Putih (Rattus norvegicus) Jantan, Prosiding Seminar Nasional TOI XXVII.
Sudjarwo, S. A., 2003, Potensi Kurkumin Sebagai Antiinflamasi pada Mencit yang Diinduksi dengan Karagen, Med. Ked. Vet., Jakarta.

Vogel, H.G., 2008, Drug Discovery and Evaluation :Pharmacological Assays, second edition, Springer. 